American Journal of BioScience
2017; 5(3): $42-53$
http://www.sciencepublishinggroup.com/j/ajbio
doi: $10.11648 /$ jajbio.20170503.12
ISSN: $2330-0159$ (Print); ISSN: $2330-0167$ (Online)

\title{
The Study of Biofield Energy Treatment Based Herbomineral Formulation in Skin Health and Function
}

\author{
Johanne Dodon ${ }^{1}$, Mahendra Kumar Trivedi ${ }^{1}$, Alice Branton ${ }^{1}$, Dahryn Trivedi ${ }^{1}$, Gopal Nayak ${ }^{1}$, \\ Mayank Gangwar ${ }^{2}$, Snehasis Jana ${ }^{2, *}$ \\ ${ }^{1}$ Trivedi Global, Inc., Henderson, USA \\ ${ }^{2}$ Trivedi Science Research Laboratory Pvt. Ltd., Bhopal, India
}

Email address:

publication@trivedisrl.com (S. Jana)

${ }^{*}$ Corresponding author

\section{To cite this article:}

Johanne Dodon, Mahendra Kumar Trivedi, Alice Branton, Dahryn Trivedi, Gopal Nayak, Mayank Gangwar, Snehasis Jana. The Study of Biofield Energy Treatment Based Herbomineral Formulation in Skin Health and Function. American Journal of BioScience.

Vol. 5, No. 3, 2017, pp. 42-53. doi: 10.11648/j.ajbio.20170503.12

Received: March 30, 2017; Accepted: April 19, 2017; Published: May 9, 2017

\begin{abstract}
The aim of the study was to evaluate the effect of the The Trivedi Effect ${ }^{\circledR}$ - Consciousness Energy Healing Treatment based new proprietary herbomineral formulation and cell medium (DMEM) on various skin health parameters using HFF-1, HaCaT, and B16-F10 cell lines. It contained minerals (zinc chloride, sodium selenate, and sodium molybdate), Lascorbic acid, along with the mixture of Centella asiatica extract and tetrahydrocurcumin (THC). The test formulation and DMEM were divided into two parts each, one part of each was coded as untreated (UT), while the second part of each was treated with the Biofield Treatment by Johanne Dodon and denoted as the Biofield Energy Treated (BT) test items. MTT assay result showed that the test formulation was safe and nontoxic up to $80 \mu \mathrm{g} / \mathrm{mL}$ concentration. The fibroblast cell proliferation assay using BrdU method showed a significant increased cell proliferation at $2.13,8.75$, and $17.53 \mu \mathrm{g} / \mathrm{mL}$ by $3.90 \%, 14.68 \%$ and $29.54 \%$, respectively in the BT-DMEM + BT-Test formulation group compared to the untreated group. The collagen data showed an increased synthesis by $7.42 \%$ and $3.84 \%$ in the UT-DMEM + BT-Test formulation and BT-DMEM + BT-Test formulation groups, respectively at $0.625 \mu \mathrm{g} / \mathrm{mL}$ with respect to the untreated group. Similarly, the elastin synthesis was increased by $19.8 \%$ and $25.8 \%$ in the UT-DMEM + BT-Test formulation and BT-DMEM + BT-Test formulation groups, respectively at $5 \mu \mathrm{g} / \mathrm{mL}$ with respect to the untreated group. However, the Biofield Energy Treated test formulation showed an increased level of hyaluronic acid by $1.7 \%$ in UT-DMEM + BT-Test formulation group compared to the untreated group. Melanin synthesis inhibition was observed by $15.21 \%$ and $11.43 \%$ in UT-DMEM + BT-Test Formulation and BT-DMEM + BT-Test Formulation groups, respectively at $0.125 \mu \mathrm{g} / \mathrm{mL}$ compared with the untreated group in B16-F10 melanoma cell line. Anti-wrinkling effects showed an improved cell viability by $7.65 \%$ at $1.25 \mu \mathrm{g} / \mathrm{mL}$ in the BT-DMEM + BT-Test formulation experimental group compared with the untreated test group. In addition, the Biofield Energy Treated Test formulation/DMEM showed a significant wound healing activity and high cellular migration of fibroblast and keratinocytes in HFF-1 and HaCaT cells, respectively. Overall, the data suggested that Biofield Treated formulation/DMEM could be helpful for skin healing, improvement the skin health, elasticity, and tightness, as well as, improving skin health issues such as wrinkling, pigmentation disorders, redness, swelling, skin cancer, aging, rashes, and skin sagging.
\end{abstract}

Keywords: Consciousness Energy Healing Treatment, Extracellular Matrix, HaCaT, HFF-1, Hyaluronic Acid, Skin Protection, Scratch Assay, Tetrahydrocurcumin

\section{Introduction}

The natural products in combination with the minerals, which have been developed in the last couple of decades have greatly evolved as indicated by their significant positive impact on cellular, molecular, genetic, and biochemical pathways in various chronic diseases. Herbal extract based formulations are the main field of biological interest of the 
pharmaceutical and agrochemical industries, and herbomineral formulations have been increased worldwide by more than $30 \%$. However, in cosmetology, most of the natural product are the principle active constituents [1]. This continued herbal based formulation interest might be due to its lower incidence of adverse effects compared with the synthetic medicines $[2,3]$. In addition, modern cosmetology is also focused on the use of raw materials rather than with synthetic chemicals in manufacturing the skin based products, due to the wide number of active ingredients. These phyto-constituents skin based caring products have supposed to have significant antioxidant and anti-inflammatory activity [4]. In general, neither active principles nor molecule targets are well defined that helps to understand the mechanism of new formulation. Skin care products with plant materials have been used to provide UV-B protection and skin whitening activity without any side effects [5]. Based on the literature data, a new proprietary herbomineral formulation was formulated, which is the combination of minerals (zinc chloride, sodium selenate, and sodium molybdate), Lascorbic acid, along with herbal extract, Centella asiatica and tetrahydrocurcumin (THC).

Minerals are the active ingredients for the skin care formulation such as zinc, copper, and selenium. Zinc is an essential cofactor for various metalloenzymes. They protect the skin against photodamage induced by UV irradiation. Besides minerals, vitamins are the preferred choice due to their significant antimicrobial, antioxidant, free radical scavenging effect, and many more activities. Micronutrients such as vitamin $\mathrm{C}, \mathrm{E}$ and $\mathrm{A}$ along with minerals play a vital role in maintaining the skin integrity and are responsible for the differentiation of keratinocytes and collagen synthesis [6]. In addition to minerals, Centella asiatica, commonly known as Gotu kola or Tiger Grass, from family Apiaceae, has been used as alternative medicine for hundreds of years for its dermatological action. It has been reported to improve the rate of healing in small wounds, scratches, hypertrophic wounds, burns, anti-inflammatory and antioxidant activity [7]. Similarly, turmeric (Curcuma longa) is the well-defined dietary spice and coloring agent. Besides, its major constituent curcumin has been reported with outstanding medicinal activities along with its use in skin health. The major metabolite of curcumin is tetrahydrocurcumin (THC). THC is a polyphenolic compound with various pharmacological action and high antioxidant potential [8]. THC has different molecular targets, signaling pathways and cellular responses [9] along with various inflammation protection, atherosclerotic lesions treatment, hepatotoxicity and nephrotoxicity [10]. In addition, THC has been reported to play a beneficial role in angiogenesis and improve the accumulation of extracellular matrix (ECM) components.

The Complementary and Alternative Medicines (CAM) have been reported with several benefits in cosmetology. The Biofield Energy Healing is one alternative approach against many pathological conditions. Energy Medicine and healing in dermatology has been studied and reported with significant outcomes [11]. The National Center for Complementary and
Alternative Medicine (NCCAM) also defined Biofield as energy medicine in CAM therapies [12, 13]. Biofield Energy is regarded as the cumulative effect of low electromagnetic field around the human body and process of energy healing is known as "Biofield Energy Treatment". Therefore, human has the ability to harness the energy from environment or universe and can transmit it into living organism or nonliving object(s) around the globe. The Biofield Energy Healing (The Trivedi Effect $\left.{ }^{\circledR}\right)$ has been reported to offer significant results in living and non-living materials. The results have been reported in the field of microbiology [14-16], cancer cell line study [17], altered anti-mycobacterial susceptibility [18], invitro study against HIV and cytomegalo virus [19], agricultural science [20-23], pharmaceuticals [24-26], and in materials science [27-29].

With the significant applications of Biofield Energy Healing Treatments, the current study was undertaken to evaluate The Trivedi Effect ${ }^{\circledR}$-Consciousness Energy Healing Treatment on the test formulation and DMEM against a wide range of skin rejuvenating parameters as a nutraceutical. The skin health parameters in the study were performed using human foreskin fibroblast, human keratinocytes, and mouse melanoma cell lines (i.e. HFF-1, HaCaT, and B16-F10).

\section{Materials and Methods}

\subsection{Chemicals and Reagents}

L-ascorbic acid as a positive control was purchased from Alfa-Aesar, while Kojic acid and 3-(4, 5-diamethyl-2thiazolyl) 2, 5 diphenyl-2 H-tetrazolium) (MTT) were purchased from Sigma Chemical Co. (St. Louis, MO). Epidermal growth factor (EGF) was procured from Gibco, ThermoFisher, USA. ELISA kits for estimation of extracellular matrix component were procured from CUSABIO and CusAb Co. Pvt. Ltd, USA. The test formulation contained zinc chloride purchased from TCI, Japan, sodium selenate from Alfa-Aesar, USA, while sodium molybdate from Sigma-Aldrich. Tetrahydrocurcumin and Centella asiatica extract were procured from Novel Nutrients Pvt. Ltd., India and Sanat Products Ltd., India, respectively. Fetal bovine serum (FBS) and DMEM were purchased from Gibco, USA. Antibiotics solution (Penicillin-Streptomycin) procured from HiMedia, India, while Direct Red 80 and EDTA were purchased from Sigma, USA. All the other chemicals used in this experiment were analytical grade available in India.

\subsection{Cell Culture}

HFF-1 (human fibroblast) cells were procured from American Type Culture Collection (ATCC), USA, originated from normal human skin fibroblast cells. B16-F10 (mouse melanoma) and $\mathrm{HaCaT}$ (human keratinocytes) cells were procured from National Centre for Cell Science (NCCS), Pune, India. HFF-1, HaCaT, and B16-F10 cell lines were maintained in the growth medium DMEM supplemented with $15 \%$ FBS, with added antibiotics penicillin $(100 \mathrm{U} / \mathrm{mL})$ 
and streptomycin $(100 \mu \mathrm{g} / \mathrm{mL})$. The growth condition of cell lines were $37^{\circ} \mathrm{C}, 5 \% \mathrm{CO}_{2}$, and $95 \%$ humidity. L-ascorbic acid (for ECM, UV-B protection, and wound healing assay) in concentrations range from $10 \mu \mathrm{M}$ to $1000 \mu \mathrm{M}$, while kojic acid (for melanin) concentrations range from $1 \mathrm{mM}$ to 10 $\mathrm{mM}$. FBS $(0.5 \%)$ was used in cell proliferation assay in BrdU assay, while EGF $10 \mu \mathrm{M}$ was used in non-cytotoxic concentration in MTT assay.

\subsection{Experimental Design}

The experimental groups consisted of cells in the normal control group, vehicle control group (0.05\% DMSO), positive control group (L-ascorbic acid/kojic acid/EGF/FBS) and experimental tested groups, which included the combination of Biofield Energy Treated and untreated Test formulation/DMEM. It consisted of four major treatment groups on specified cells with UT-DMEM + UT-Test formulation, UT-DMEM + Biofield Treated Test formulation (BT-Test formulation), BT-DMEM + UT-Test formulation, and BT-DMEM + BT-Test formulation.

\subsection{Energy of Consciousness Treatment Strategies}

The test formulation and DMEM were divided into two parts. One part of the test samples were treated with the Biofield Energy by a renowned Biofield Energy Healer (also known as The Trivedi Effect ${ }^{\mathbb{R}}$ ) and coded as the Biofield Energy Treated samples, while the second part of the test samples did not receive any sort of treatment and was defined as the untreated test samples. This Biofield Energy Healing Treatment was provided by Johanne Dodon, who participated in this study and performed the Biofield Energy Treatment remotely. The Biofield Energy Healer was remotely located in the Canada, while the test samples were located in the research laboratory of Dabur Research Foundation near New Delhi, India. This Biofield Energy Treatment was administered for 5 minutes through the Healer's unique Energy Transmission process remotely to the test samples under laboratory conditions. The Biofield Energy Healer, Johanne Dodon, in this study never visited the laboratory in person, nor had any contact with the test formulation and medium. Further, the control group was treated with a sham healer for comparison purpose. The sham healer did not have any knowledge about the Biofield Energy Treatment. After that, the Biofield Energy Treated and untreated samples were kept in similar sealed conditions for experimental study.

\subsection{Determination of Non-cytotoxic Concentrations}

The cell proliferation in cell lines such as HFF-1, HaCaT, and B16-F10 were performed by MTT assay. The cells counted and plated in 96 well plates at the density corresponding to $5 \times 10^{3}$ to $10 \times 10^{3}$ cells/well $/ 180 \mu \mathrm{L}$ of cell growth medium. The cells were incubated overnight under specific growth conditions that were allowed the cell recovery and exponential growth, which were subjected to serum stripping or starvation. The cells were subsequently treated to the Biofield Energy Treated and untreated test
formulation/DMEM at a range of concentrations ( 0.008 to 10 $\mu \mathrm{g} / \mathrm{mL})$ and ascorbic acid $(10$ and $50 \mu \mathrm{M})$ followed by incubation from 24 to 72 hours in $\mathrm{CO}_{2}$ incubator at $37^{\circ} \mathrm{C}, 5 \%$ $\mathrm{CO}_{2}$ and $95 \%$ humidity. Further, serum free MTT media (20 $\mu \mathrm{L}$ of $5 \mathrm{mg} / \mathrm{mL}$ ) was added to each well followed by incubation for 3 hours at $37^{\circ} \mathrm{C}$. The supernatant was aspirated and $150 \mu \mathrm{L}$ of DMSO was added to each well to dissolve the formazan crystals. Thereafter, the absorbance of each well was recorded at $540 \mathrm{~nm}$ using Synergy HT micro plate reader, BioTek, USA. The concentrations that exhibited percentage cytotoxicity of less than $30 \%$ was considered as non-cytotoxic [30].

\subsection{Effect of the Test Formulation on Human Fibroblast (HFF-1) Cell Proliferation Using BrdU Method}

HFF-1 cells were counted using hemocytometer and plated in 96 well plate at the density corresponding to $1 \mathrm{X} 10^{3}$ to 5 $\mathrm{X} 10^{3}$ cells/well in DMEM supplemented with $15 \%$ FBS. The cells were then incubated overnight under growth conditions so as to allow cell recovery and exponential growth. Following overnight incubation, the above cells were subjected to serum starvation. After serum starvation, the cells were treated with non-cytotoxic concentrations of test formulation in different defined experimental groups and positive control. Subsequent 24 to 72 hours of incubation with the test substance and positive control, the plates were taken out and BrdU (5-bromo-2'-deoxyuridine) was estimated using Cell Proliferation ELISA, BrdU estimation kit (ROCHE - 11647229001) as per manufacturer's instructions.

\subsection{Estimation of Extracellular Matrix Component Synthesis}

Synthesis of extracellular matrix components (i.e. collagen, elastin and hyaluronic acid) in HFF-1 cell line were estimated for determining the potential of test formulation to improve skin strength, overall elastin, and hydration level. HFF-1 cells were counted using hemocytometer and plated in 48 well plate at the density corresponding to $10 \times 10^{3}$ cells/well in DMEM supplemented with $15 \%$ FBS. The cells were then incubated overnight under specified growth conditions followed by cells to serum stripping. Further, the cells were treated with the Biofield Energy Treated test formulation at different experimental combination groups with DMEM group viz. vehicle control (DMSO, 0.05\%), and positive control (ascorbic acid, at $10 \mu \mathrm{M}$ ). Further, after 72 hours of incubation with the test items and positive control, the supernatants from all the cell plates were taken out and collected in pre-labeled centrifuge tubes for the estimation elastin and hyaluronic acid levels. However, the corresponding cell layers were processed for estimation of collagen levels using Direct Sirius red dye binding assay. Elastin and hyaluronic acid were estimated using ELISA kits from Cusabio Biotech Co. Ltd, Human Elastin ELN Elisa kit 96T and Human Hyaluronic Acid Elisa kit 96T, respectively [31]. 


\subsection{Estimation of Melanin Synthesis- Skin Depigmentation Effect}

B16-F10 cells were used for melanin synthesis estimation, cells were counted using hemocytometer and plated in $90 \mathrm{~mm}$ culture plate at the density corresponding to $2 \times 10^{6} / 6 \mathrm{~mL}$ in the culture plates. Further, the cells were incubated overnight under specified growth conditions and allowed for cell recovery and exponential growth. After incubation, the cells were treated with $\alpha$ melanocyte-stimulating hormone $(\alpha-\mathrm{MSH})$ for a time point ranging from 4 to 24 hours for stimulation of intracellular melanin synthesis. Further, the cells were incubated with $\alpha-\mathrm{MSH}$, and then treated with concentration at $0.625,1.25$ and $2.5 \mu \mathrm{g} / \mathrm{mL}$ of test formulation with DMEM for a time period from 48 to 96 hours. After incubation, intracellular melanin was extracted in $\mathrm{NaOH}$ and the absorbance was recorded at $405 \mathrm{~nm}$. The level of melanin was extrapolated using a standard curve obtained from purified melanin [32].

\subsection{Anti-wrinkling Effects of Test Formulation on HFF-1 Cells against $U V$-B Induced Stress}

UV-B induced stress was evaluated in HFF-1 cells and cell viability was estimated in the presence of test formulation. The cells were counted using hemocytometer and plated in 96 well plate at the density corresponding to $5 \times 10^{3}$ to $10 \mathrm{X}$ $10^{3}$ cells/well in DMEM supplemented with 15\% FBS cells/plates, which were incubated overnight under growth conditions to allow cell recovery and exponential growth. The cells were treated with non-cytotoxic concentrations of test formulation for 2 to 24 hours. After treatment, the cells were subjected to lethal dose of UV-B irradiation (200 $\left.\mathrm{mJ} / \mathrm{cm}^{2}\right)$ that can lead to approx. $50 \%$ cytotoxicity $(302 \mathrm{~nm}$, CL-1000 M, UVP, USA) [33]. The percent cell viability was assessed using formula (equation 1)-

$$
\% \text { Cell viability }=(\mathrm{X} / \mathrm{R}) * 100
$$

Where $\mathrm{X}$ represents the absorbance of cells corresponding to positive control and test groups, and $\mathrm{R}$ represents the absorbance of cells corresponding to baseline (control cells) group.

\subsection{Wound Healing Scratch Assay}

HFF-1 and HaCaT cell lines were counted using hemocytometer and plated in 12 well plates at the densities $0.08 \times 10^{6} /$ well $/ \mathrm{mL}$ of cell growth medium. The cells were incubated overnight under growth conditions and allowed cell recovery and exponential growth. After overnight incubation, the cells were subjected to the serum starvation in DMEM for 24 hours. Mechanical scratches that represents wounds were created in the near confluent monolayer of cells by gently scraping with the sterile 200 $\mu \mathrm{L}$ micropipette tip. The cells were then rinsed with serum free DMEM and the Biofield Energy Treated test formulation. The scratched area was then monitored for a time period ranging from 0 to 48 hours for closure of wound area. The photomicrographs were taken at 16 hours for quantitative assessment of migrated cells using digital camera, which was connected to the inverted microscope. All the observations were calculated and compared with positive and vehicle control [34].

\subsection{Statistical Analysis}

Each experiment was carried out in three independent assays and was represented as mean values with standard error of mean (SEM). Student's $t$-test was used to compare two groups to judge the statistical significance. For multiple group comparison, one-way analysis of variance (ANOVA) was used followed by post-hoc analysis using Dunnett's test. Statistically significant values were set at the level of $p \leq 0.05$.

\section{Results and Discussions}

\subsection{Non-cytotoxic Effect of Test Formulation on Cell Lines}
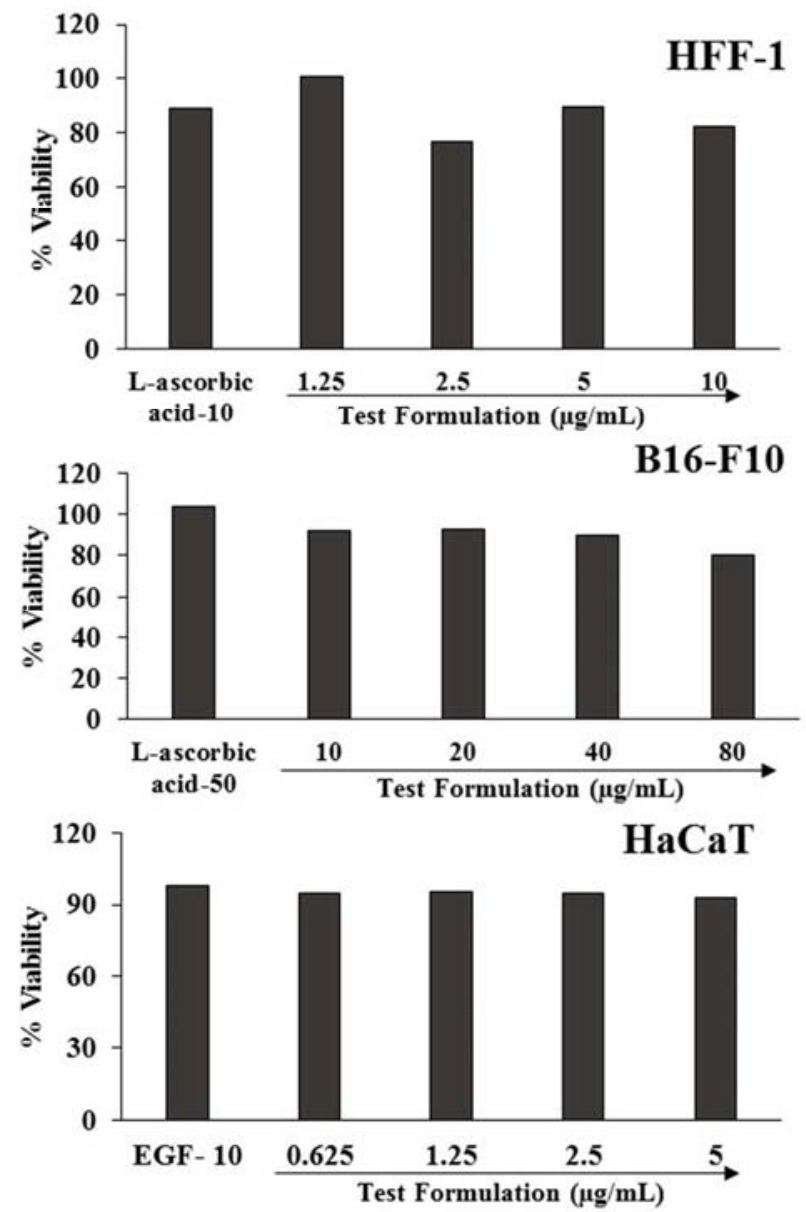

Figure 1. Concentration-dependent effect of test formulation on HFF-1, B16-F10, and HaCaT cell lines for cell viability. Percentage viability in cell lines were evaluated by treating the cells with test formulation at highest concentration $10 \mu \mathrm{g} / \mathrm{mL}$ for 72 hours. Cell viability was determined using the MTT assays, and results are expressed as percent viability in the cells. EGF-10: Epidermal growth factor $(10 \mu M)$ and L-ascorbic acid at 10 and $50 \mu \mathrm{M}$ in HFF-1 and B16-F10 cells, respectively. 
The three cell lines i.e. HFF-1, HaCaT and B16-F10 were used for the study and treated with the combination of the Biofield Energy Treated test formation/DMEM as per detailed experimental design. The positive control ascorbic acid $(10$ and $50 \mu \mathrm{M})$ and EGF $(10 \mathrm{ng} / \mathrm{mL})$ was used at defined concentrations for estimation of percentage viability. The results of percent cell viabilities in all the tested cell lines are presented in Figure 1. The percent cell viability data showed that the cell viability range in all the cell lines in presence of the test formulation was in the range of $77 \%$ to $103 \%$ among all the tested cell lines. In HFF-1 cell line, cell viability range was $77 \%$ to $100 \%$ for test formulation and for ascorbic acid it was found as $89 \%$ (Figure 1A). Similarly, in B16-F10 cell line, the cell viability range was $80 \%$ to $92 \%$ in test formulation and it was found as $103 \%$ in ascorbic acid group (Figure 1B). In addition, HaCaT cell lines showed $77 \%$ to $100 \%$ cell viability range in test formulation groups and in ascorbic acid, it was found as $89 \%$ (Figure 1C). These data suggest that the test formulation was found safe at the tested dose range up to maximum of $80 \mu \mathrm{g} / \mathrm{mL}$ against the tested cell lines.

\subsection{Effect of the Biofield Energy Treated Test Formulation on Human Fibroblast Cell (HFF-1) Proliferation (BrdU Method)}

The cellular proliferation effect of different combinations of the Biofield Energy Treated/Untreated test formulation with DMEM on cellular proliferation in HFF-1 cells was evaluated after 48 hours of incubation using BrdU assay. The percentage cell proliferation of the Biofield Energy Treated test formulation in combination with DMEM and positive control in HFF-1 cells is represented in Figure 2. The study results showed that the FBS (positive control) proliferation rate was significantly improved compared with the normal and vehicle control group by $150 \%$. However, a significant increase in the cell proliferation was found to be $2.22 \%$ and $23.66 \%$ at two concentration 2.13 and $17.5 \mu \mathrm{g} / \mathrm{mL}$ respectively, in UT-DMEM + BT-Test Formulation group compared with the UT-DMEM + UT-Test Formulation group. In addition, BT-DMEM + BT-Test Formulation group showed an increased cell proliferation rate by $3.90 \%, 14.68 \%$ and $29.54 \%$ at the concentration $2.13,8.75,17.53 \mu \mathrm{g} / \mathrm{mL}$, respectively compared with the UT-DMEM + UT-Test Formulation group.

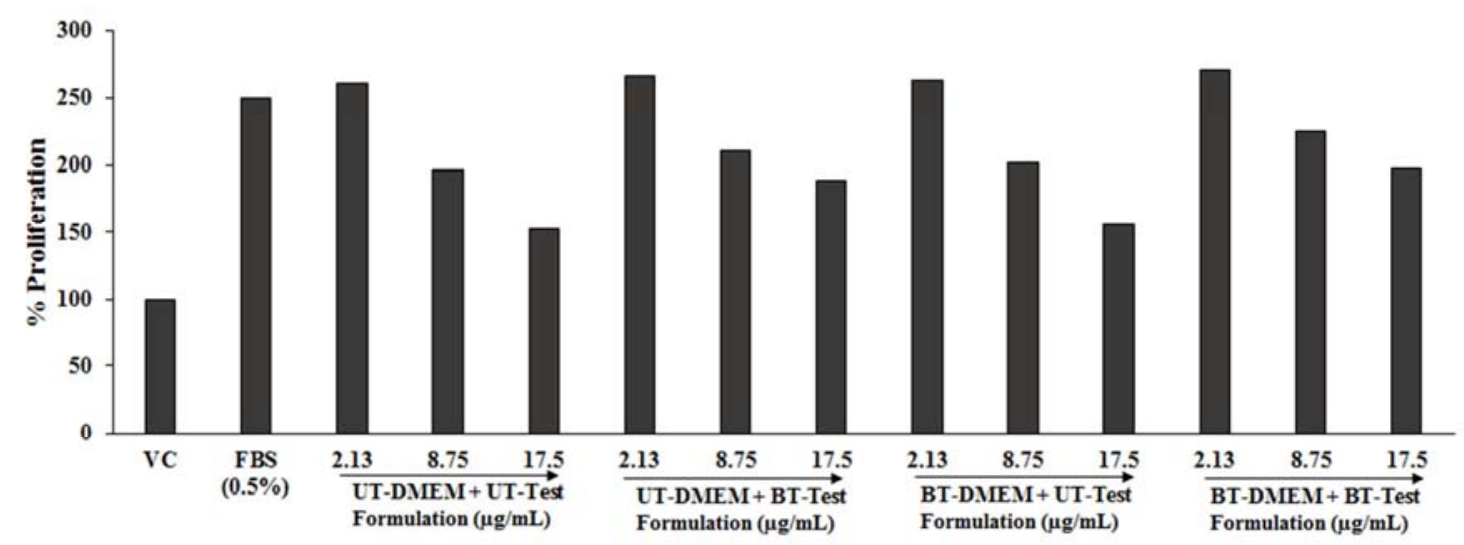

Figure 2. Effect of the Biofield Energy Treated test formulation in combination with DMEM on cellular proliferation in HFF-1 cells after 48 hours. ${ }^{* *} p \leq 0.01$ and ${ }^{*} p \leq 0.05$ statistical comparison with respect to untreated DMEM and untreated test formulation using one way ANOVA (Dunnett's test), VC: Vehicle control; UT: Untreated; BT: Biofield Treated.

\subsection{Estimation of Extracellular Matrix Component Synthesis}

The effect of the Biofield Energy Treated Test Formulation was researched in order to evaluate the extra cellular matrix components (ECM) to study their role in skin strength, hydration level and overall skin elasticity. ECM components like collagen, elastin and hyaluronic acid were evaluated in HFF-1 cell line. The results of the study are presented as collagen, elastin, and hyaluronic acid levels.

\subsubsection{Analysis of Collagen}

The effect of the Biofield Energy Treated Test Formulation on collagen levels showed a significant increase in the content of collagen amount at concentrations range from 0.625 to $2.5 \mu \mathrm{g} / \mathrm{mL}$ on HFF-1 cell line. The experimental results of collagen with respect to positive control, ascorbic acid and the Biofield Energy Treated Test
Formulation are presented in Figure 3. Ascorbic acid (10 $\mu \mathrm{M})$ showed a significant increased level of collagen content by $44.8 \%$, while the Biofield Energy Treated Test Formulation reported with increased percentages of collagen amounts by $3.84 \%$ to $7.42 \%$ at various concentrations. The tested groups UT-DMEM + BT-Test Formulation at concentration $0.625 \mu \mathrm{g} / \mathrm{mL}$ showed $7.42 \%$ increase in collagen level compared to the untreated DMEM and Test Formulation (UT-Test Formulation + UTDMEM). Similarly, the Biofield Energy Treated Test Formulation and Biofield Energy Treated DMEM (BTDMEM + BT-Test Formulation) at concentration 0.625 $\mu \mathrm{g} / \mathrm{mL}$ showed $3.84 \%$ increase in collagen level compared to the UT-Test Formulation + UT-DMEM. These study data suggest that the Biofield Energy Treated Test Formulation and Biofield Energy Treated DMEM showed a notable increase in collagen level. 


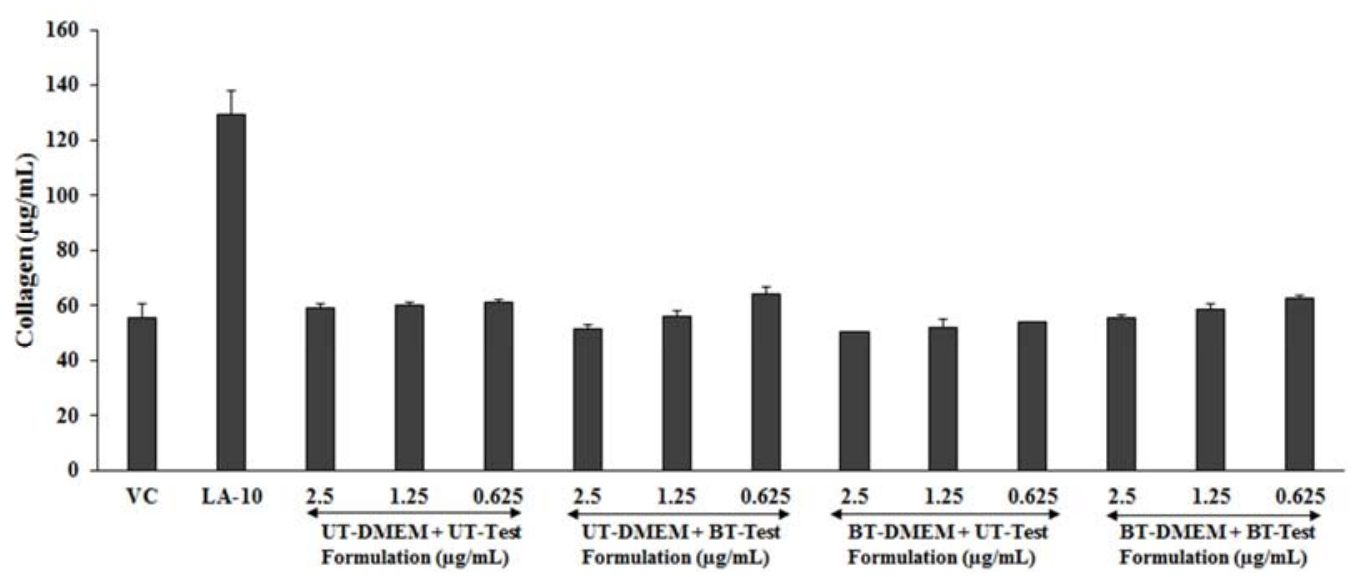

Figure 3. Concentration-dependent effects of test formulation on human dermal fibroblast (HFF-1) cell line for collagen level. VC: Vehicle control; LA-10: $L$ Ascorbic acid; UT: Untreated; BT: Biofield Treated.

Different biomechanical aspects have been controlled by extra cellular matrix components (ECM) such as tissue differentiation, morphogenesis, and homeostasis. Collagen, elastin, and hyaluronic acid are all the major skin components required for skin health and ageing. Among all, collagen is the most abundant fibrous protein present in $\mathrm{ECM}$, while $30 \%$ of the total protein mass is constituted in multicellular animals. Besides, its major roles are chemotaxis support and migration, tensile strength, and regulate the cell adhesion, tissue development, mechanical strength and skin texture [35]. Hence, the quantity and quality of the collagen regulates the skin health. It might be expected that Biofield Energy Healing Treatment might improve the tropocollagen molecules, which showed an increased collagen fibril and its content. The present experiment concluded significant increased level of collagen by the Biofield Energy (The Trivedi Effect ${ }^{\mathbb{B}}$ ) Treated test formulation, which would be useful and have application in skin health and its appearance. This finding suggests the significant role of The Trivedi Effect $^{\circledR}$ in cosmetics in order to improve the collagen level that might help to delay the skin ageing.

\subsubsection{Analysis of Elastin}

The effect of the Biofield Energy Treated test formulation on elastin level and results are presented in Figure 4. The results showed a significant increase in the elastin synthesis in the Biofield Energy Treated Test Formulation in HFF-1 cell line. Ascorbic acid $(50 \mu \mathrm{M})$ group showed an increased elastin content by $55.4 \%$ compared with baseline control values. However, the Biofield Energy Treated Test Formulation showed an increased percentages of elastin amounts by $12.8 \%$ and $25.8 \%$ at dose range from 2.5 to 10 $\mu \mathrm{g} / \mathrm{mL}$ respectively. However, among the tested experimental test formulation groups, UT-DMEM + BT-test formulation showed a significantly $(p \leq 0.05)$ increased elastin concentration by $18.8 \%$ and $19.8 \%$ at 10 and $5 \mu \mathrm{g} / \mathrm{mL}$, respectively compared to UT- Test Formulation + UTDMEM. Similarly, BT-DMEM + BT-Test Formulation group showed a significantly $(p \leq 0.05)$ increase the level of elastin by $25.8 \%$ and $12.8 \%$ at 5 and $10 \mu \mathrm{g} / \mathrm{mL}$, respectively compared to the UT-Test Formulation + UT-DMEM. Therefore, the Biofield Energy Treated test formulation can be concluded to be a significant alternative approach in order to improve the elastin level compared with the treated DMEM.

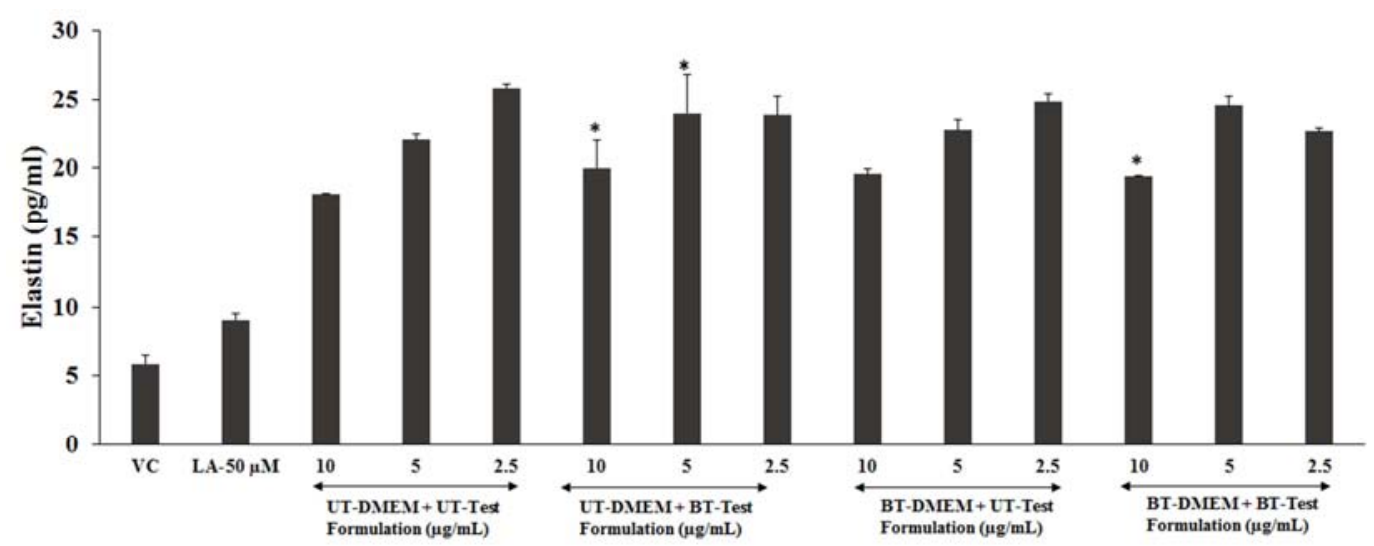

Figure 4. Concentration-dependent effect of Biofield Energy Treated test formulation on human dermal fibroblast (HFF-1) cell line for elastin level. ${ }^{*} \leq \leq .05$ compared with untreated DMEM and untreated test formulation (using Student's t-test). VC: Vehicle control; LA-50: L-Ascorbic acid at $50 \mu M$ concentration; UT: Untreated; BT: Biofield Treated. 
Elastin is considered as another important component in ECM, it controls the stretch conditions and also provides recoil to the tissues. It forms a tight junction with collagen fibrils and has a strong association. Elastin fibers are covered by the glycoprotein microfibrils that mostly have fibrillins that are important for the integrity of the elastin fiber [36]. An increased level of elastin is important for skin, as it regulates and activates the dermal metabolism. It might be expected that Biofield Energy Treatment improves the synthesis of elastin fibres via. glycoprotein microfibrils. Experimental data suggest that Biofield Energy Treatment (The Trivedi Effect ${ }^{\circledR}$ ) on test formulation has the capacity to significantly increased elastin synthesis, which could be useful for cell growth, survival, differentiation and morphogenesis.

\subsubsection{Analysis of Hyaluronic Acid}

The effect of the Biofield Energy Treated test formulation on the level of hyaluronic acid was evaluated in the presence of ascorbic acid as standard in HFF-1 cell line (Figure 5). The results of hyaluronic acid showed a significant increase in the hyaluronic acid content by $1.7 \%$ at concentration range from 0.625 to $2.5 \mu \mathrm{g} / \mathrm{mL}$ in UT-DMEM + BT-Test Formulation group compared with the UT-DMEM + UT-Test Formulation. All the experimental groups showed a change in hyaluronic acid, and showed a significant an increase with respect to the baseline control. However, rest of the other groups showed alterations with respect to UT-Test Formulation + UT-DMEM and baseline control groups. It can be hypothesized that Biofield Energy might increase the synthesis of HA, which would be helpful for overall skin health. Therefore, it might be expected that the Biofield Energy Healing based test formulation and Biofield Energy Treated DMEM can be used as an approach to improve the hyaluronic acid content.

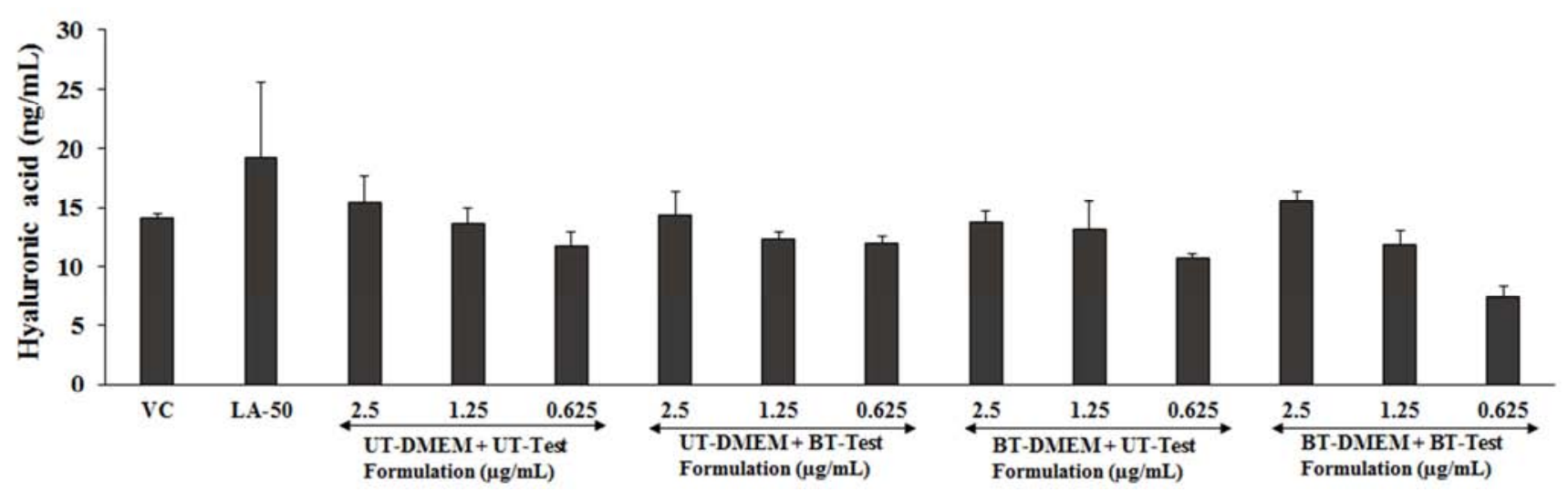

Figure 5. Synthesis of extracellular matrix component, hyaluronic acid by the Biofield Energy Treated test formulation in human dermal fibroblasts (HFF-1) cell lines. VC: Vehicle control; LA-50: L-Ascorbic acid at $50 \mu M$ concentration; UT: Untreated; BT: Biofield Treated.

Other important ECM component is the hyaluronic acid (HA), which plays an important role in retaining the skin moisture. Skin accounts for the maximum content of HA (about $50 \%$ of body HA), which helps in joints lubrication, activation of inflammatory cells, angiogenesis, hydration, tissue repair, provide framework to blood vessels, and fibroblast migration. In addition, it regulates the water balance and osmotic pressure in skin structure present in extracellular domain of cell surfaces, and help to stabilize. Nowadays, HA skin treatment has been increasingly used clinically in many skin disorders [37]. The study results suggest an improved level of HA in the experimental Biofield Energy Treated test formulation and DMEM groups. However, the Biofield Energy Healing based test formulation has shown a highly increased level of HA, which can be used as an alternative approach for skin disorders. Overall, it can be concluded that The Trivedi Effect $\left.^{(}\right)$has the capacity to regulate the skin moisture by maintain the HA level.

\subsection{Estimation of Melanin Synthesis Inhibition}

The effect of the Biofield Energy Treated test formulation on melanogenesis mouse melanoma (B16-F10) cell lines were cultured in DMEM supplemented media containing various concentrations of the test formulation along with positive control, kojic acid $(10 \mu \mathrm{M})$ for 48 to 96 hours. The results of the percentage decrease in the $\alpha-\mathrm{MSH}$ induced melanin synthesis in all the experimental groups are presented in Figure 6. Kojic acid was used as positive control, a skin whitening compound, which is used in many cosmetic products showed $63.98 \%$ reduction in melanin level. However, the effect of the Biofield Energy Treated test formulation showed a significant decrease in melanin synthesis at concentrations 0.0125 to $0.125 \mu \mathrm{g} / \mathrm{mL}$. Moreover, UT-DMEM + BT-Test Formulation and BTDMEM + BT-Test Formulation group showed a significant decrease in melanin synthesis by $5.79 \%$ and $10.32 \%$ at concentration $0.0125 \mu \mathrm{g} / \mathrm{mL}$, respectively compared with the UT-DMEM + UT-Test Formulation. Similarly, at concentration $0.0625 \mu \mathrm{g} / \mathrm{mL}$ in groups such as UT-DMEM + BT-Test Formulation and BT-DMEM + BT-Test Formulation group showed a significant inhibition of melanogenesis by $15.21 \%$ and $11.43 \%$ at $0.125 \mu \mathrm{g} / \mathrm{mL}$ compared with the UT-DMEM + UT-Test Formulation 
group. However, in UT-DMEM + BT-Test Formulation and BT-DMEM + UT-Test Formulation experimental group showed a significant inhibition of melanogenesis by $10.39 \%$ and $15.11 \%$ at concentration $0.125 \mu \mathrm{g} / \mathrm{mL}$ compared with the UT-Test Formulation + UT-DMEM in
B16-F10 melanoma cell line. Therefore, it can be concluded that the Biofield Energy Healing based test formulation and Biofield Energy Treated DMEM would be useful approach to decrease melanogenesis.

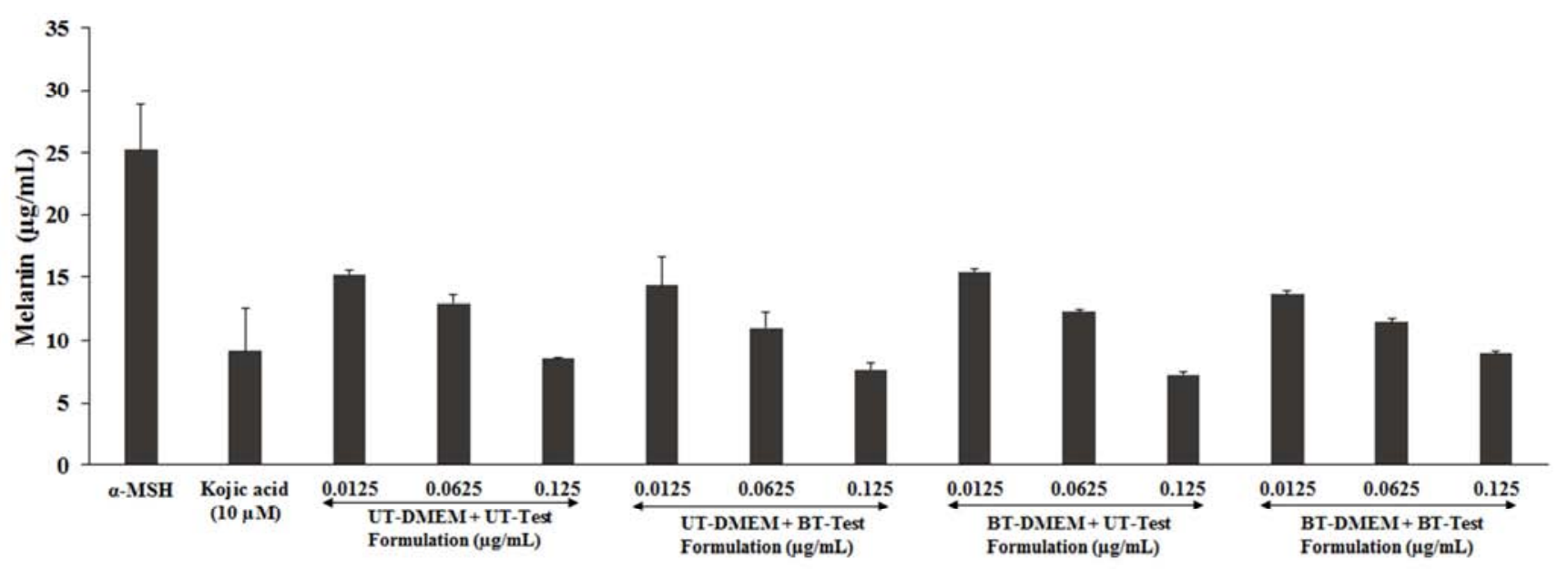

Figure 6. Inhibitory effect of Biofield Energy Treated Test Formulation on melanogenesis (skin whitening potential) in mouse melanoma (B16-F10) cell line. a-MSH: Alpha Melanocyte-stimulating hormone; UT: Untreated; BT: Biofield Treated.

Melanogenesis initiated once the skin nuclei cells become damaged by the sun ultraviolet radiations (UV-A and UV-B). Melanin is synthesized from melanocytes and present in the basal layer of the epidermis. The radiation exposed on the skin's surface was absorbed by melanin resulting in skin darkening. Currently, many synthetic cosmetics along with natural products are available in worldwide market to control the skin darkening. The common natural ingredients present in cosmetics for whitening of skin are azelaic acid, aloesin, piperlonguminine, eugenol, and curcuminoids, and many more [38]. However, the Biofield Energy Healing based test formulation is a novel approach for various skin-related disorders. The test formulation is the combination of herbal components and minerals, and many scientific evidence suggesting the role of minerals, Centella asiatica extract and THC (strong antioxidant activity) for the treatment of inflammatory dermatoses, skin infections, wound healing, along with cosmetic preparations have been reported [39, 40]. The experimental results showed a significant decrease in the percentage $\alpha$-MSH melanin synthesis at different tested concentrations of the Biofield Energy Treated Test formulation and showed better effects with respect to the standard drug, kojic acid. It might be expected that the Biofield Energy Treated test formulation inhibits the tyrosinase enzymes required for melanogenesis [41]. However, Biofield Energy Treatment (The Trivedi Effect ${ }^{\circledR}$ ) on the test formulation and DMEM has shown a significant inhibition of melanogenesis compared with other experimental combinations and with the untreated test formulation and DMEM. Hence, The Trivedi Effect ${ }^{\circledR}$ can be a good alternative treatment approach as compared with the synthetic compounds for skin whitening.

\subsection{Anti-wrinkling Effects of Test Formulation on UVB-Induced Photoaging}

The effect of the Biofield Energy Treated test formulation in UV-B induced stress in HFF-1 cells and the cell viability was identified using hemocytometer. Antiwrinkling effects and their cell viability from UV-B rays are presented in Figure 7 . The cells were subjected to lethal dose of UV-B irradiation $\left(200 \mathrm{~mJ} / \mathrm{cm}^{2}\right)$ and percentage cell viability due to UV-B was evaluated. The HFF-1 cells while exposure of UV-B showed high degree of cell death with only $25.21 \%$ of cell viability. In vehicle control (DMSO, $0.05 \%$ ), the cell viability was significantly decreased to $27.78 \%$ due to UV-B irradiation $\left(200 \mathrm{~mJ} / \mathrm{cm}^{2}\right)$. However, ascorbic acid $(50 \mu \mathrm{M})$ showed an increased cell viability i.e. $43 \%$ improved UV-B protection. Among the tested groups, UT-DMEM + BTTest formulation, BT-DMEM + UT-Test formulation groups did not showed a significant protection compared with the UT-DMEM + UT-Test formulation group. However, improved cell viability was observed by $7.65 \%$ and $1.44 \%$ at 1.25 and $0.625 \mu \mathrm{g} / \mathrm{mL}$ in the BT-DMEM + BT-Test formulation experimental group compared with the UT-DMEM + UT-Test formulation group. This suggests that the Biofield Energy Treated test formulation could be used for significantly results in skin protective effect with anti-wrinkling potential. 


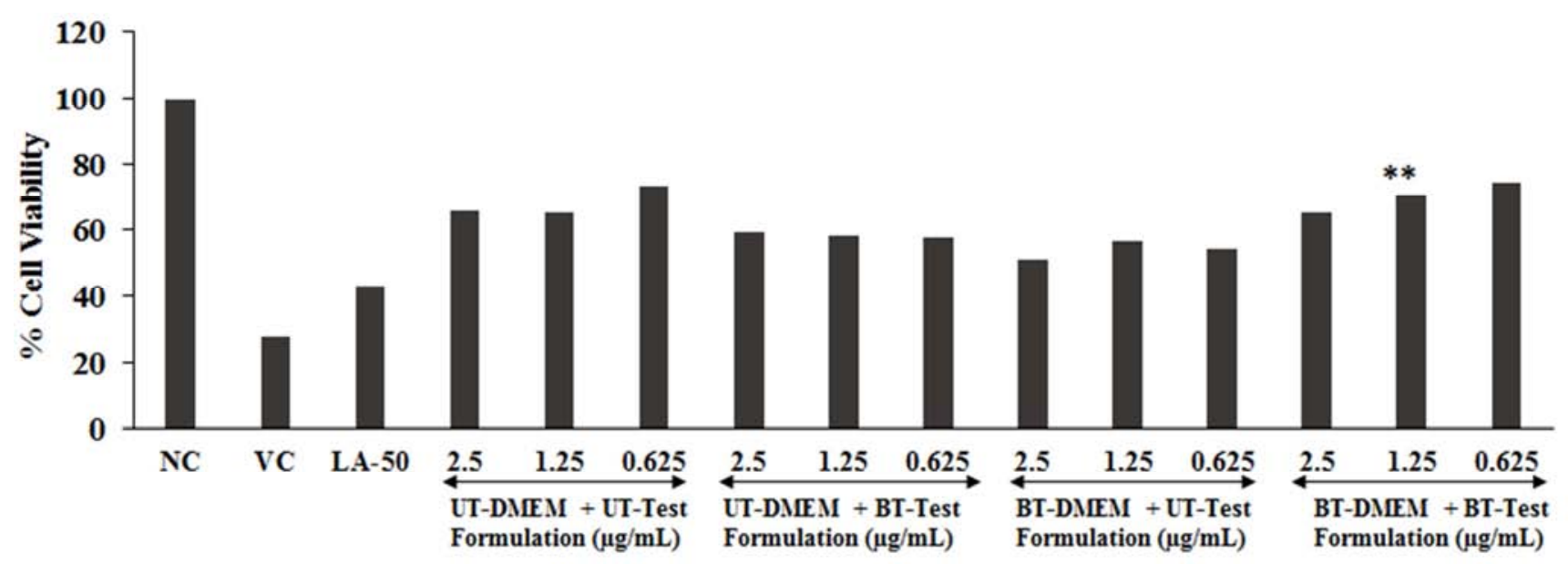

Figure 7. Anti-wrinkling potential and cytoprotective potential of Biofield Energy Treated test formulation against UV-B induced stress in human dermal fibroblasts (HFF-1) cell lines. \% cell viability of HFF-1 cells after treatment in various groups. NC: Normal control; VC: Vehicle control (DMSO, 0.05\%); LA50: L-Ascorbic acid at $50 \mu \mathrm{M}$ concentration. UT: Untreated; BT-Biofield Treated. ${ }^{* *} p \leq 0.01$ represents statistical comparison with untreated group using one way ANOVA (Dunnett's test).

The effect of the Biofield Energy Treated test formulation along with DMEM showed a significant protection against UVB-induced skin damage. UVBinduced skin related disorders are directly related with the skin ageing. It will induce stress and results in generation of free radicals, which further downregulates the signal transduction in human skin fibroblasts. This phenomenon will lead to DNA damage and induce various inflammatory responses [42]. Further, UV-B also leads to the reduction the procollagen and elastin expression by inhibiting the receptor activation of Smad protein. From the present experiment, it was found that the ECM components i.e. elastin, collagen, and hyaluronic acid were significantly increased after the Biofield Energy Treatment along with UV-B protection and improved cell viability. Hence, it can be suggested that the Biofield Energy Treated test formulation and DMEM would protect the skin and cell viability from UV-B radiation along with improved ECM components, which directly improve the skin health.

\subsection{Wound-Healing Scratch Assay}

The wound healing effect of the Biofield Energy Treated test formulation and DMEM was tested using in vitro scratch assay, which measured the rate of HFF-1 and $\mathrm{HaCaT}$ cells migration. The representative cell migration photographs in different groups were monitored and shown in Figure 8. Confluent monolayer of cells were scratched and the migration rate was recorded at different time points. Some represented photographs showed a significant migration of cells at different time points. Further, significant wound closure and cell migration was monitored at 16 hours in the presence of Biofield Energy Treated test formulation compared with the vehicle control and ascorbic acid (Figure 8). From the experimental observations, it was found that the migration rate of HFF-1 fibroblasts cells and $\mathrm{HaCaT}$ keratinocytes cells were significantly increased by monitored scratch area for closure of wound. However, the ascorbic acid showed a significant wound closure and migration in Figure 8 (b) compared with baseline control group in Figure 8 (a). Similarly, the Biofield Treated test formulation in UT-DMEM + BT-Test Formulation experimental group showed a significant rate of cellular migration rate along with wound closure as shown in Figure 8 (d), compared with the UT-Test Formulation + UTDMEM group.

To evaluate the cellular migration, in vitro scratch assay is defined as a suitable, well-developed model. It also monitors the intracellular event during cell migration and cell-cell and matrix interactions during wound healing process [43]. In order to repair the damaged skin, cell migration and proliferation and collagen deposition are the important events required for recovery. Fibroblasts cells manage the collagen deposition that would be required to repair the injured area. They provide strength, integrity and structure to skin and related with replication and migration of cells, which helps in collagen synthesis. All the components of the test formulation were reported to have an important role in cosmetology and the wound healing process [39, 44]. However, role of the Biofield Energy Treated Test Formulation suggests the significant proliferation of fibroblasts possibly by antioxidant mechanism. Hence, the Biofield Energy Treated (The Trivedi Effect ${ }^{\mathbb{B}}$ ) Test Formulation and DMEM might be alternative approach in wound healing and the repair process. 


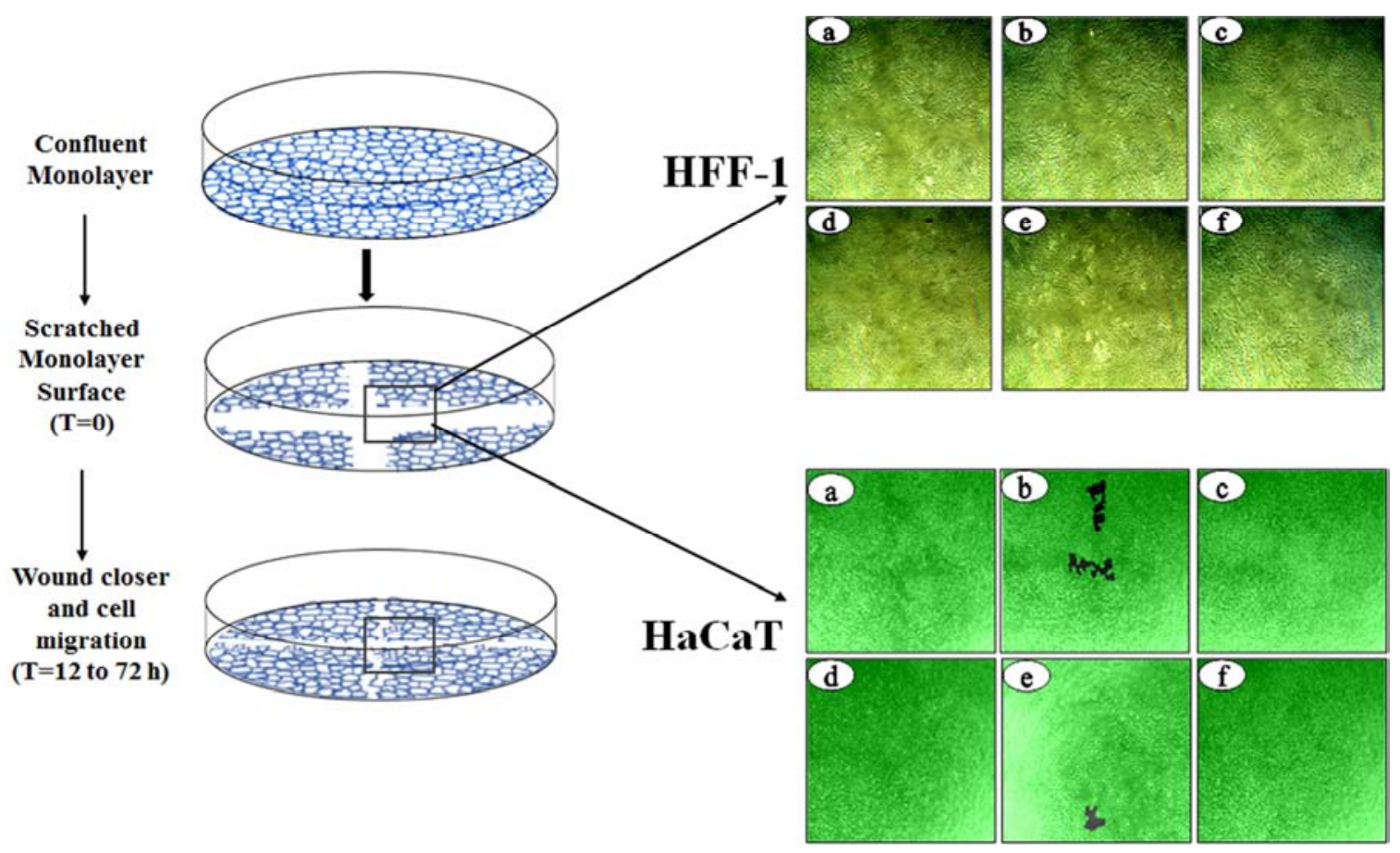

Figure 8. Representative pictures of HFF-1 and HaCaT cell migration cells after induction of a scratch. All the pictures were taken immediately after the scratch was induced (i.e. at 0 hours), after 16 hours in the presence of ascorbic acid and Biofield Energy Treated test formulation. Pictures are taken at 50 times magnification. Images represents HFF-1 cells migration in presence of (a) baseline control media, (b) ascorbic acid, (c) UT-DMEM + UT-Test Formulation, (d) UT-DMEM + BT-Test Formulation, (e) BT-DMEM + UT-Test Formulation, and BT-DMEM + BT-Test Formulation.

\section{Conclusions}

The current study established the potential application of the Biofield Energy (The Trivedi Effect ${ }^{\circledR}$-Consciousness Energy Healing Treatment) based test formulation and cell medium with respect to the different skin health parameters using human fibroblasts, human keratinocytes, and mouse melanoma cell lines (i.e. HFF-1, HaCaT, and B16-F10). MTT assay results showed that the test formulation was found to be safe up to $80 \mu \mathrm{g} / \mathrm{mL}$ concentration. Fibroblast proliferation assay in HFF-1 cells showed a significant proliferation rate at $2.13,8.75$, and $17.53 \mu \mathrm{g} / \mathrm{mL}$ by $3.90 \%$, $14.68 \%$ and $29.54 \%$ in the BT-DMEM + BT-Test formulation group compared to the untreated group. Among tested ECM components, $3.84 \%$ to $7.42 \%$ increases in collagen were reported compared with the untreated test formulation and DMEM. Similarly, the elastin level was increased by $19.8 \%$ and $25.8 \%$ in UT-DMEM + BT-Test Formulation $(5 \mu \mathrm{g} / \mathrm{mL} ; p \leq 0.05)$ and BT-DMEM + BT-Test Formulation $(5 \mu \mathrm{g} / \mathrm{mL} ; \quad p \leq 0.01)$ groups, respectively compared with the UT-Test Formulation and UT-DMEM. In addition, the level of hyaluronic acid was increased by $1.7 \%$ in UT-DMEM + BT-Test Formulation group compared with untreated test formulation and DMEM. Besides, melanin synthesis inhibition was found to be in range of $5.79 \%$ to $15.21 \%$ in different groups, while UT-DMEM + BT-Test Formulation and BT-DMEM + BT-Test Formulation group showed a maximum inhibition of melanin synthesis by $15.21 \%$ and $11.43 \%$, respectively at $0.125 \mu \mathrm{g} / \mathrm{mL}$ compared with the untreated Test Formulation and DMEM in B16-F10 melanoma cell line. An anti-wrinkling effects using UV-B induced stress in HFF-1 cells of the Biofield Treated test formulation showed $7.65 \%$ improved cell viability in the BTDMEM + BT-Test Formulation experimental group at 1.25 $\mu \mathrm{g} / \mathrm{mL}$ compared with the UT-DMEM + UT-Test formulation group. The wound-healing scratch assay showed a significantly increased cellular proliferation and migration in HFF-1 and HaCaT cells in the Biofield Energy Treated Test Formulation compared with the untreated test formulation and DMEM. Overall, the Biofield Energy Healing (The Trivedi Effect ${ }^{\mathbb{B}}$ ) based test formulation has shown substantial protective effects on skin disorders such as wound healing, wrinkling, ageing and hyperpigmentation. Therefore, the Biofield Energy based novel herbal pharmaceuticals might be a suitable approach for the development for herbal cosmetics and their formulation, which can improve the overall skin health care with respect to anti-wrinkling, skin-whitening, anti-ageing, and rejuvenating action.

Overall, the Biofield Energy Treated test formulation can be used as a Complementary and Alternative Medicine (CAM) with a safe therapeutic index for various skin irregularities that are typically symptoms of a skin disorders such as Eczema, warts, acne, hives, ringworm, Rosacea, psoriasis, skin cancer, wrinkles, diaper rash, seborrheic dermatitis, chickenpox, measles, rashes from bacterial or fungal infections, rashes from allergic reactions, raised bumps that are red or white, scaly or rough skin, peeling skin, ulcers, open sores or lesions, dry, cracked skin, discolored patches of skin, fleshy bumps, warts, or other skin growths, changes in mole color or size, a loss of skin pigment, 
excessive flushing. Further, the Biofield Energy Healing Treatment can also be used in the prevention of temporary and permanent skin disorders, anti-aging, and in the improvement of overall health and quality of life.

\section{Abbreviations}

THC: Tetrahydrocurcumin, ECM: Extracellular matrix, EGF: Epidermal growth factor, $\alpha$-MSH: $\alpha$-Melanocytestimulating hormone, ANOVA: One-way analysis of variance, HA: Hyaluronic acid; HFF-1: Human foreskin fibroblast cell line, B16-F10: Mouse melanoma cell line; HaCaT: Human Keratinocytes cells; UVB: Ultra violet B rays; CAM: Complementary and alternative medicine; NCCAM: National Center for Complementary and Alternative Medicine.

\section{Acknowledgements}

Authors are grateful to Dabur Research Foundation, Trivedi Global, Inc., Trivedi Science, Trivedi Testimonials, and Trivedi Master Wellness for their support throughout the work.

\section{References}

[1] Helmstädter A, Staiger C (2014) Traditional use of medicinal agents: a valid source of evidence. Drug Discov Today 19: 47.

[2] Goyal RK (2005) Investigation of Cellular and Molecular Mechanisms for Anti-diabetic Drugs with Special Reference to Unani and Ayurvedic Herbal Medicines. In: Traditional System of Medicine, Abdin, M. Z. and Y. P. Abrol (Eds.). Narosa Publishing House, New Delhi.

[3] WHO (1993) Research Guideline for Evaluating the Safety and Efficacy of Herbal Medicines. World Health Organization, Manila, Philippines.

[4] Gao XH, Zhang L, Wei H, Chen HD (2008) Efficacy and safety of innovative cosmeceuticals. Clin Dermatol 26: 36774.

[5] Chanchal D, Swarnlata S (2008) Novel approaches in herbal cosmetics. J Cosmet Dermatol 7: 89-95.

[6] Park K (2015) Role of Micronutrients in Skin Health and Function. Biomol Ther (Seoul) 23: 207-217.

[7] Brinkhaus B, Lindner M, Schuppan D, Hahn EG (2000) Chemical, pharmacological and clinical profile of the East Asian medical plant Centella asiatica. Phytomedicine 75: 427-448.

[8] Lai CS, Wu JC, Yu SF, Badmaev V, Nagabhushanam K, Ho CT, Pan MH (2011) Tetrahydrocurcumin is more effective than curcumin in preventing azoxymethane-induced colon carcinogenesis. Mol Nutr Food Res 55: 1819-1828.

[9] Aggarwal BB, Deb L, Prasad S (2015) Curcumin differs from tetrahydrocurcumin for molecular targets, signaling pathways and cellular responses. Molecules 20: 185-205.
[10] Naito M, Wu X, Normura H, Kodama M, Kato Y, Osaswa T (2002) The protective effect of tetrahydrocurcumin on oxidative stress in cholesterol-fed rabbits. J Atheroscler Thromb 9: 243-250.

[11] Shenefelt PD (2014) Energy medicine in dermatology. In: Norman RA, Shenefelt PD, Rupani RN, editors. Integrative Dermatology. Oxford University Press, New York, NY, USA.

[12] Cooper EL (2007) The immune system and complementary and alternative medicine. Evidence-based complementary and alternative medicine : eCAM 4: 5-8.

[13] Clarke TC, Black LI, Stussman BJ, Barnes PM, Nahin RL (2015) Trends in the use of complementary health approaches among adults: Unites States, 2002-2012. National health statistics reports; no 79. Hyattsville, MD: National Center for Health Statistics.

[14] Trivedi MK, Patil S (2008) Impact of an external energy on Staphylococcus epidermis [ATCC-13518] in relation to antimicrobials susceptibility and biochemical reactions-an experimental study. J Accord Integr Med 4: 230-235.

[15] Trivedi MK, Patil S (2008) Impact of an external energy on Yersinia enterocolitica [ATCC-23715] in relation to antimicrobials susceptibility and biochemical reactions: an experimental study. Internet J Alternat Med 6: 13.

[16] Trivedi MK, Bhardwaj Y, Patil S, Shettigar H, Bulbule A (2009) Impact of an external energy on Enterococcus faecalis [ATCC-51299] in relation to antimicrobials susceptibility and biochemical reactions-an experimental study. J Accord Integr Med 5: 119-130.

[17] Trivedi MK, Patil S, Shettigar H, Gangwar M, Jana S (2015) In vitro evaluation of biofield treatment on cancer biomarkers involved in endometrial and prostate cancer cell lines. J Cancer Sci Ther 7: 253-257.

[18] Trivedi MK, Patil S, Shettigar H, Mondal SC, Jana S (2015) An impact of biofield treatment: antimycobacterial susceptibility potential using BACTEC 460/MGIT-TB System. Mycobact Dis 5:189.

[19] Trivedi MK, Branton A, Trivedi D, Nayak G, Mondal SC, Jana S (2015) In vitro evaluation of biofield treatment on viral load against human immunodeficiency-1 and cytomegalo viruses. American Journal of Health Research 3: 338-343.

[20] Trivedi MK, Tallapragada RM, Branton A, Trivedi D, Nayak G, Mondal S, Jana S (2015) Impact of biofield energy treatment on soil fertility. Earth Sciences 4: 275-279.

[21] Trivedi MK, Tallapragada RM, Branton A, Trivedi D, Nayak G, Mondal S, Jana S (2015) Evaluation of biochemical marker - Glutathione and DNA fingerprinting of biofield energy treated Oryza sativa. American Journal of BioScience. 3: 243248.

[22] Trivedi MK, Branton A, Trivedi D, Nayak G, Mondal SC, Jana S (2015) Morphological characterization, quality, yield and DNA fingerprinting of biofield energy treated alphonso mango (Mangifera indica L.). Journal of Food and Nutrition Sciences 3: 245-250.

[23] Trivedi MK, Branton A, Trivedi D, Nayak G, Mondal SC, Jana S (2015) Evaluation of plant growth, yield and yield attributes of biofield energy treated mustard (Brassica juncea) and chick pea (Cicer arietinum) seeds. Agriculture, Forestry and Fisheries 4: 291-295. 
[24] Trivedi MK, Tallapragada RM, Branton A, Trivedi D, Nayak G, Bairwa K, Jana S (2015) Physical, thermal, and spectroscopic characterization of biofield energy treated potato micropropagation medium. American Journal of Bioscience and Bioengineering 3: 106-113.

[25] Trivedi MK, Patil S, Shettigar H, Bairwa K, Jana S (2015) Spectroscopic characterization of chloramphenicol and tetracycline: An impact of biofield. Pharm Anal Acta 6: 395.

[26] Trivedi MK, Patil S, Shettigar H, Bairwa K, Jana S (2015) Spectroscopic characterization of biofield treated metronidazole and tinidazole. Med Chem 5: 340-344.

[27] Trivedi MK, Nayak G, Patil S, Tallapragada RM, Latiyal O, Jana S (2015) Impact of biofield treatment on atomic and structural characteristics of barium titanate powder. Ind Eng Manage 4: 166.

[28] Trivedi MK, Nayak G, Tallapragada RM, Patil S, Latiyal O, Jana S (2015) Effect of biofield treatment on structural and morphological properties of silicon carbide. J Powder Metall Min 4: 132

[29] Trivedi MK, Nayak G, Patil S, Tallapragada RM, Latiyal O (2015) Evaluation of biofield treatment on physical, atomic and structural characteristics of manganese (II, III) Oxide. J Material Sci Eng 4: 177.

[30] Plumb JA (2004) Cell sensitivity assays: The MTT assay. Methods Mol Med 88:165-169.

[31] Hahn MS, Kobler JB, Starcher BC, Zeitels SM, Langer R (2006) Quantitative and comparative studies of the vocal fold extracellular matrix. I: Elastic fibers and hyaluronic acid. Ann Otol Rhinol Laryngol 115: 156-164.

[32] Zhang L, Yoshida T, Kuroiwa Y (1992) Stimulation of melanin synthesis of B16-F10 mouse melanoma cells by bufalin. Life Sci 51: 17-24.

[33] Wen KC, Shih IC, Hu JC, Liao ST, Su TW, Chiang HM (2011) Inhibitory effects of Terminalia catappa on UVB-Induced photodamage in fibroblast cell line. Evid Based Complement Alternat Med 2011: 904532.

[34] Fronza M, Heinzmann B, Hamburger M, Laufer S, Merfort I (2009) Determination of the wound healing effect of
Calendula extracts using the scratch assay with 3T3 fibroblasts. J Ethnopharmacol 126: 463-467.

[35] Rozario T, DeSimone DW (2010) The extracellular matrix in development and morphogenesis: A dynamic view. Dev Biol 341: $126-40$.

[36] Frantz C, Stewart KM, Weaver VM (2010) The extracellular matrix at a glance. J Cell Sci 123: 4195-4200.

[37] Weindl G, Schaller M, Schäfer-Korting M, Korting HC (2004) Hyaluronic acid in the treatment and prevention of skin diseases: Molecular biological, pharmaceutical and clinical aspects. Skin Pharmacol Physiol 17: 207-213.

[38] Wattanakrai P, Suwanachote S, Kulkollakarn S, Rajatanavin N (2007) The study of human skin irritation of a novel herbal skin care product and ingredients by human single closed patch testing. J Med Assoc Thai 90: 1116-1122.

[39] Bylka W, Znajdek-Awiżeń P, Studzińska-Sroka E, Brzezińska M (2013) Centella asiatica in cosmetology. Postepy Dermatol Alergol 30: 46-49.

[40] Prasad S, Tyagi AK, Aggarwal BB (2014) Recent developments in delivery, bioavailability, absorption and metabolism of curcumin: The golden pigment from golden spice. Cancer Res Treat 46: 2-18.

[41] Busca R, Ballotti R (2000) Cyclic AMP a key messenger in the regulation of skin pigmentation. Pigment Cell Res 13: 6069.

[42] Ho JN, Lee YH, Lee YD, Jun WJ, Kim HK, Hong BS, Shin DH, Cho HY (2005) Inhibitory effect of Aucubin isolated from Eucommia ulmoides against UVB induced matrix metalloproteinase-1 production in human skin fibroblasts. Biosci Biotechnol Biochem 69: 2227-2231.

[43] Liang CC, Park AY, Guan JL (2007) In vitro scratch assay: A convenient and inexpensive method for analysis of cell migration in vitro. Nat Protoc 2: 329-333.

[44] Sumiyoshi M, Kimura Y (2009) Effects of a turmeric extract (Curcuma longa) on chronic ultraviolet B irradiation-induced skin damage in melanin-possessing hairless mice. Phytomedicine 16: 1137-1143. 